\title{
Recent advances in the molecular mechanisms causing primary generalized glucocorticoid resistance
}

\author{
Nicolas C. Nicolaides, ${ }^{1,2}$ Agaristi Lamprokostopoulou, ${ }^{2}$ \\ Amalia Sertedaki, ${ }^{1}$ Evangelia Charmandari ${ }^{1,2}$
}

${ }^{1}$ Division of Endocrinology, Metabolism and Diabetes, First Department of Pediatrics, University of Athens Medical School, 'Aghia Sophia' Children's Hospital; '2Division of Endocrinology and Metabolism, Center of Clinical, Experimental Surgery and Translational Research, Biomedical Research Foundation of the Academy of Athens; Athens, Greece

\begin{abstract}
Primary Generalized Glucocorticoid Resistance is a rare condition characterized by generalized, partial, target tissue insensitivity to glucocorticoids owing to inactivating mutations, insertions or deletions in the human glucocorticoid receptor (hGR) gene (NR3C1). Recent advances in molecular and structural biology have enabled us to elucidate the molecular mechanisms of action of the mutant receptors and to understand how certain conformational alterations of the defective hGRs result in generalized glucocorticoid resistance. Furthermore, our everincreasing understanding of the molecular mechanisms of glucocorticoid action indicates that the glucocorticoid signaling pathway is a stochastic system that plays a fundamental role in maintaining both basal and stress-related homeostasis. In this review, we summarize the clinical manifestations and molecular pathogenesis of Primary Generalized Glucocorticoid Resistance, we present our recent findings from the functional characterization of three novel heterozygous point mutations in the $\mathrm{NR} 3 \mathrm{Cl}$ gene, and we discuss the diagnostic approach and therapeutic management of the condition. When the condition is suspected, we recommend sequencing analysis of the $N R 3 C 1$ gene as well as of other genes encoding proteins involved in the glucocorticoid signal transduction. The tremendous progress of next-generation sequencing will undoubtedly uncover novel hGR partners or cofactors.
\end{abstract}

Key words: Glucocorticoids, Glucocorticoid receptor, Glucocorticoid resistance, Glucocorticoid signaling, NR3C1 mutations

Address for correspondence:

Nicolas C. Nicolaides, MD, PhD. Division of Endocrinology and Metabolism, Center of Clinical, Experimental Surgery and Translational Research, Biomedical Research Foundation of the Academy of Athens, 4 Soranou tou Efessiou Street, Athens, 11527, Greece; Tel.: +30 2106597041, Fax: +30 2106597545, E-mail: nnicolaides@bioacademy.gr

Received:18-11-2015, Accepted: 11-12-2015

\section{INTRODUCTION}

Glucocorticoids (cortisol in humans, corticosterone in most rodents) are steroid hormones secreted by the adrenal cortex into the systemic circulation in an ultradian, circadian, and stress-related fashion under the control of the hypothalamic-pituitary-adrenal (HPA) axis. ${ }^{1-4}$ These cholesterol-derived molecules 
participate in the physiologic function of almost all organs and play a fundamental role in the stress response. ${ }^{5}$ Glucocorticoids exert their pleiotropic effects through their cognate receptor, which belongs to the steroid receptor family of the nuclear receptor superfamily. ${ }^{6}$ The glucocorticoid receptor functions as a ligand-activated transcription factor that influences the transcription rate of numerous genes through well-described genomic and less well understood nongenomic actions. ${ }^{1,2,4-6}$ Since glucocorticoids contribute substantially to the steady state of the organism, it is generally accepted that glucocorticoid signaling is not merely a simplified signal transduction pathway but a complex homeostatic system that functions coordinately with other systems to help the organism cope with stressful stimuli. ${ }^{2,5,7}$

Homeostatic mechanisms, including the HPA axis, exert their effects in an inverted U-shaped dose-response curve $e^{2,5,7}$ (Figure 1). Normal basal homeostasis

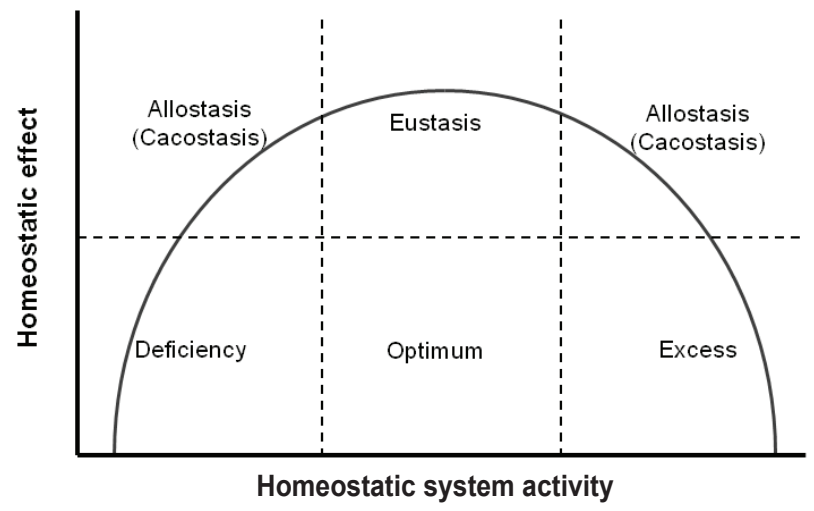

Figure 1. The inverted U-shaped dose-response curve. Eustasis is achieved in the middle range of the homeostatic system activity, whereas allostasis or cacostasis occurs when the homeostatic system activity is deficient or excessive. or eustasis is achieved in the central, optimal range of the curve, whereas suboptimal effects may occur on either side of the curve and can lead to insufficient adaptation, a state that has been called allostasis or cacostasis. ${ }^{2,5,7}$ The latter states of hypofunction or hyperfunction of the HPA axis may have short-term or long-term adverse consequences for the individual and can lead to a compromised sense of well-being and/or performance. ${ }^{7-9}$ At the molecular level, any alterations in the glucocorticoid signal transduction are likely to result in impaired tissue sensitivity to glucocorticoids, which may present with clinical manifestations of glucocorticoid resistance or glucocorticoid hypersensitivity (Table 1). ${ }^{10-14}$ One such allostatic condition is Primary Generalized Glucocorticoid Resistance. ${ }^{11-18}$

\section{PATHOPHYSIOLOGY AND CLINICAL MANIFESTATIONS}

Primary Generalized Glucocorticoid Resistance is a rare familial or sporadic allostatic condition in which almost all organs have a different degree of insensitivity to glucocorticoids. ${ }^{11-18}$ This decreased tissue responsiveness to glucocorticoids leads to compensatory activation of the HPA axis that causes hypersecretion of adrenocorticotropic hormone (ACTH) by the anterior pituitary gland. The increased concentrations of ACTH cause adrenal cortex hypertrophy and activate the enzymatic biosynthetic pathway of cortisol, adrenal androgens [androstenedione, dehydroepiandrosterone (DHEA), and DHEA-sulfate (DHEAS)], and steroid precursors with mineralocorticoid activity (deoxycorticosterone and corticosterone). ${ }^{11-18}$

Patients with Primary Generalized Glucocorticoid

Table 1. Expected clinical manifestations in tissue-specific glucocorticoid excess or hypersensitivity and deficiency or resistance ${ }^{11}$

\begin{tabular}{lll}
\hline Target tissue & $\begin{array}{l}\text { Glucocorticoid hypersensitivity }= \\
\text { Glucocorticoid excess }\end{array}$ & $\begin{array}{l}\text { Glucocorticoid resistance }= \\
\text { Glucocorticoid deficiency }\end{array}$ \\
\hline Central nervous system & Insomnia, anxiety, depression, defective cognition & Fatigue, somnolence, malaise, defective cognition \\
Liver & + Gluconeogenesis, + lipogenesis & Hypoglycemia, resistance to diabetes mellitus \\
Fat & Accumulation of visceral fat (metabolic syndrome) & Loss of weight, resistance to weight gain \\
Blood vessels & Hypertension & Hypotension \\
Bone & Stunted growth, osteoporosis & \\
Inflammation/immunity & $\begin{array}{l}\text { Immune suppression, anti-inflammation, } \\
\text { vulnerability to certain infections and tumors }\end{array}$ & + Inflammation, + autoimmunity, + allergy \\
\hline
\end{tabular}


Resistance may be asymptomatic or may present with clinical manifestations of mineralocorticoid and/or androgen excess. Therefore, hypertension and/or hypokalemic alkalosis can occur in patients with increased concentrations of steroid precursors with mineralocorticoid activity. ${ }^{11-18}$ Adrenal androgen excess may cause ambiguous genitalia in karyotypic females, precocious puberty, acne, hirsutism, malepattern hair loss, and hypofertility in both sexes, oligo-amenorrhea and menstrual irregularities in women, and oligospermia in men. ${ }^{11-18}$ Glucocorticoid deficiency is rare and has been reported in adults with chronic fatigue, ${ }^{16,19,20}$ in a child with hypoglycemic generalized tonic-clonic seizures during an episode of febrile illness, ${ }^{21}$ and in a newborn with profound hypoglycemia, reported easy "fatigability" with feeding, and growth hormone deficiency. ${ }^{22}$ It is worth noting that the increased $\mathrm{CRH}$ concentrations may cause anxiety and depression. ${ }^{18}$

The clinical heterogeneity of the condition is mostly due to differences in target tissue sensitivity to glucocorticoids, mineralocorticoids, and adrenal androgens among patients. ${ }^{11-18}$ Furthermore, other molecules participating in steroid signaling pathways, such as hormone inactivating or -activating enzymes, immunophilins, and heat shock proteins, as well as genetic and epigenetic factors, may contribute substantially to variations in tissue response to steroid hormones. ${ }^{15,17,18}$

\section{MOLECULAR PATHOGENESIS}

In Generalized Glucocorticoid Resistance, the decreased target-tissue sensitivity to glucocorticoids has been primarily ascribed to inactivating point mutations, insertions or deletions in the $\mathrm{NR} 3 \mathrm{Cl}$ gene, which encodes the human glucocorticoid receptor (hGR). ${ }^{11-18}$ For many years it was believed that the NR3C1 gene encoded one protein. During the last three decades, this classic dogma changed dramatically with the demonstration that the alternative use of exon $9 \alpha$ or $9 \beta$ of the $N R 3 C 1$ gene upon transcription generates the two main protein isoforms, the hGR $\alpha$ and the hGR $\beta$, which have different properties in terms of localization, ligand-binding ability, and transcriptional activity. ${ }^{23-27}$ Moreover, Lu and Cidlowski showed that the hGR $\alpha$ mRNA may be translated into eight receptor $\alpha$ isoforms (hGR $\alpha-\mathrm{A}, \mathrm{hGR} \alpha-\mathrm{B}, \mathrm{hGR} \alpha-\mathrm{C} 1, \mathrm{hGR} \alpha-\mathrm{C} 2$, hGR $\alpha-C 3$, hGR $\alpha-D 1$, hGR $\alpha-D 2$, and hGR $\alpha-D 3$ ) because of the presence of eight alternative translation initiation sites. ${ }^{28,29}$ It is likely that the hGR $\beta$ mRNA may also be translated into eight receptor $\beta$ isoforms through the same molecular mechanisms.

The classic hGR $\alpha$ is a modular protein that consists of four functional domains: i) the amino-terminal or immunogenic domain (NTD), which is the largest domain of the receptor and consists of amino acids that undergo several post-translational modifications; ii) the DNA-binding domain (DBD), which contains the conserved motif of two zinc fingers enabling the receptor to bind to DNA sequences within the promoter regions of glucocorticoid-responsive genes; iii) the hinge region, which confers the appropriate structural flexibility to the receptor and contains critical lysine residues that undergo acetylation by the transcription factor CLOCK, the circadian locomotor output cycle kaput which, together with the brain-muscle-arnt-like protein 1 (BMAL1), regulate the circadian oscillations of gene expression; and iv) the ligand-binding domain (LBD), where the receptor binds to natural or synthetic glucocorticoids. ${ }^{5,6,18,30}$ The LBD consists of twelve $\alpha$ helices and four $\beta$ sheets and contains amino acid sequences important for the ligand-induced nuclear translocation of the receptor, as well as amino acids that interact with coactivators or corepressors in a ligand-dependent fashion. . $^{5,6,18}$

At the target cell, the glucocorticoid signaling cascade is triggered upon glucocorticoid-binding to the LBD of the receptor and leads to conformational changes that result in dissociation of the receptor from heat shock proteins and immunophilins (Figure 2). ${ }^{5,6,18}$ The ligand-bound hGR $\alpha$ translocates into the nucleus, forms homo- or hetero-dimers, and binds to the specific DNA sequences, the glucocorticoid response elements (GREs), within the regulatory regions of glucocorticoid target genes, thereby inducing or repressing their expression. Alternatively, the activated hGR $\alpha$ can influence gene expression independently of DNA binding by physically interacting with other important transcription factors, such as the nuclear factor- $\kappa \mathrm{B}(\mathrm{NF}-\kappa \mathrm{B})$, the activator protein-1 (AP-1), and signal transducers and activators of transcription (STATs) (Figure 2). ${ }^{5,6,18}$ 


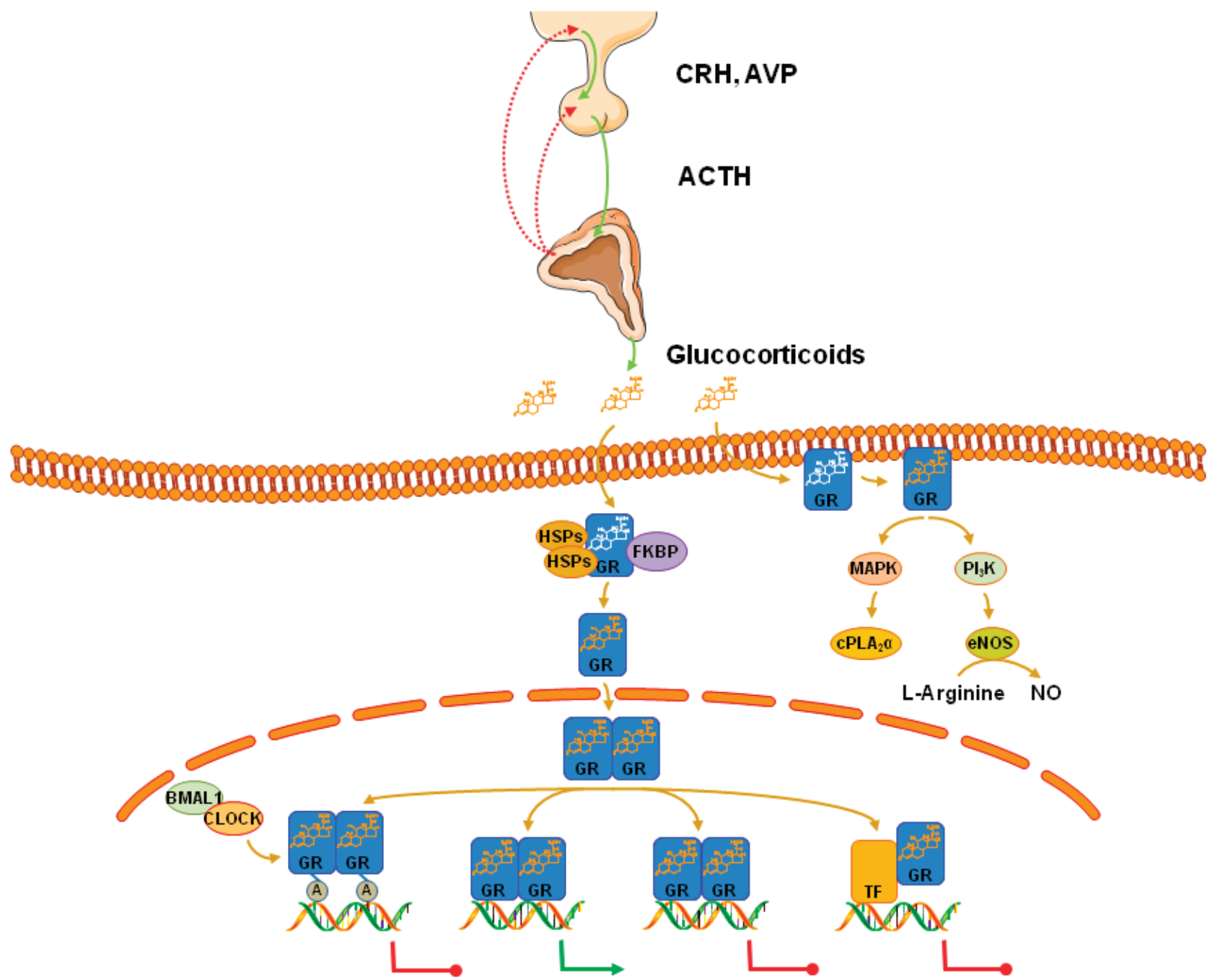

Figure 2. The HPA axis and the glucocorticoid signaling pathway. Upon stimulation of the HPA axis by numerous external or internal stressful stimuli, neurons of the paraventricular nuclei located in the hypothalamus release CRH and AVP, which both increase the production and secretion of ACTH by the anterior lobe of pituitary gland. ACTH then triggers the production of glucocorticoids, which reach every target-cell through the systemic circulation. In the target-cell, glucocorticoids bind to their cognate receptor which undergoes conformational changes, dissociates from HSPs and FKBPs, and translocates to the nucleus, where it binds as a homo- or heterodimer onto the GREs of target-genes, thereby inducing or repressing the expression of the latter. The hGR can alternatively regulate gene expression, independently of DNA binding, by physically interacting with other transcription factors (NF- $\kappa \mathrm{B}, \mathrm{AP}-1$ or STAT5). Moreover, the hGR was recently shown to undergo acetylation by the transcription factor CLOCK in a lysine cluster of its hinge region. This CLOCK-mediated post-translational modification of the hGR may provide the basis for the circadian oscillations of glucocorticoid-target genes. In addition to their genomic actions, accumulating evidence suggests that glucocorticoids may induce some effects within seconds or minutes. These nongenomic glucocorticoid actions seem to be mediated by membrane-bound hGRs which activate the mitogen-activated protein kinase (MAPK) or the phosphatidylinositol 3-kinase $\left(\mathrm{PI}_{3} \mathrm{~K}\right)$ pathways. ACTH: adrenocorticotropic hormone; AVP: arginine-vasopressin; BMAL1: brain-muscle-arnt-like protein 1; CLOCK: circadian locomotor output cycle kaput; cPLA2 $\alpha$ : cytosolic phospholipase A2 alpha; CRH: corticotropin-releasing hormone; eNOS: endothelial nitric oxide synthetase; FKBP: immunophilins; GR: glucocorticoid receptor; HSP: heat shock proteins; MAPK: mitogen-activated protein kinases; NO: nitric oxide; $\mathrm{PI}_{3} \mathrm{~K}$ : phosphatidylinositol 3-kinase; TF: transcription factor.

Primary Generalized Glucocorticoid Resistance is primarily caused by inactivating mostly heterozygous but also homozygous point mutations, insertions or deletions in the $\mathrm{NR} 3 \mathrm{Cl}$ gene that lead to a defective glucocorticoid receptor and impaired glucocorticoid signaling and cause generalized, partial tissue in- 
sensitivity to glucocorticoids. Most of the reported $N R 3 C 1$ gene mutations are located in the LBD of the receptor, three of them, however, the hGR $\alpha \mathrm{V} 423 \mathrm{~A}$, the hGR $\alpha$ R469X and the hGR $\alpha$ R477H, having been identified in the DBD (Figure 3). 19,21,22,31-47 Over the last three decades, advances in molecular and structural biology have enabled the study of the molecular mechanisms through which the mutant hGRs impair glucocorticoid signal transduction and cause the variable clinical phenotype of Primary Generalized Glucocorticoid Resistance (Table 2).

\section{THE MOLECULAR AND STRUCTURAL BIOLOGY OF THE NATURAL MUTANT RECEPTORS hGRaV423A, hGRaV575G AND hGRaH726R}

We have recently identified three novel heterozygous inactivating point mutations in the $\mathrm{NR} 3 \mathrm{Cl}$ gene causing Primary Generalized Glucocorticoid Resistance and we have applied standard molecular and structural biology methods to elucidate the molecular mechanisms of action of the mutant receptors. ${ }^{45-47}$ Specifically, we investigated: i) the ability of the mutant receptors to induce glucocorticoid-responsive genes through reporter assays; ii) the expression of the mutant receptors at the protein level via Western blotting; iii) the ability of the mutant receptors to exert a dominant negative effect upon the hGR $\alpha$ mediated transcriptional activity using reporter assays; iv) the transrepressive activity of the mutant receptors upon the NF- $\mathrm{\kappa B}-$ mediated transcriptional activity through reporter assays; $v$ ) the affinity of the mutant receptors for the ligand via dexamethasonebinding assays; vi) the subcellular localization of the mutant receptors in the absence of ligand and the time required to complete nuclear translocation following exposure to dexamethasone using green fluorescent protein (GFP)-fused plasmids; vii) the binding of the mutant receptors to GREs through in vitro binding assays; viii) the ability of the mutant receptors to interact with coactivators, such as the glucocorticoid receptor-interacting protein 1 (GRIP1) coactivator, using Glutathione-S-Transferase (GST)pull down assays; and ix) the conformational changes of the mutant receptors causing Primary Generalized Glucocorticoid Resistance through computer-based 3-dimensional simulation using crystallographic data available in public. ${ }^{45-47}$

The first patient was a 9-year-old boy who presented with anxiety, fatigue, and hypertension. ${ }^{45} \mathrm{He}$ harbored a novel heterozygous mutation in the NR3C1 gene that resulted in substitution of valine $(\mathrm{V})$ by alanine (A) at amino acid position 423 in the LBD of the receptor. ${ }^{45}$ In vitro functional studies showed that

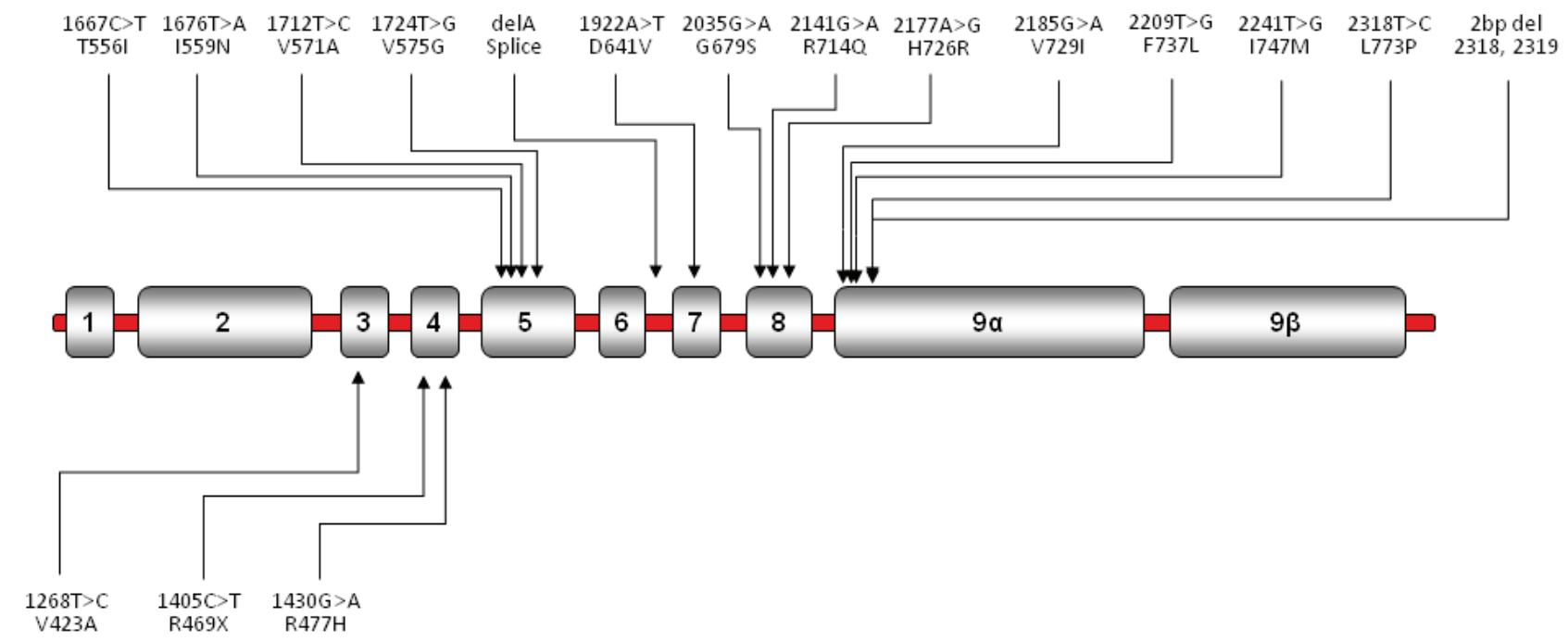

Figure 3. Schematic representation of the known mutations of the NR3C1 gene causing Primary Generalized Glucocorticoid Resistance. Mutations in the upper panel are located in the LBD of the receptor, while the V423A, R469X, and R477H mutations are located in the DBD of the receptor. 
Table 2. Mutations of the human glucocorticoid receptor gene causing Primary Generalized Glucocorticoid Resistance

\begin{tabular}{|c|c|c|c|c|c|}
\hline \multirow[b]{2}{*}{ Author (Reference) } & \multicolumn{2}{|c|}{ Mutation position } & \multirow[b]{2}{*}{ Molecular mechanisms } & \multirow[b]{2}{*}{ Genotype } & \multirow[b]{2}{*}{ Phenotype } \\
\hline & cDNA & Amino acid & & & \\
\hline 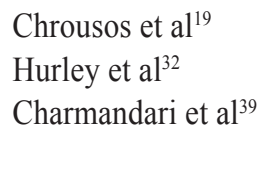 & $1922(\mathrm{~A} \rightarrow \mathrm{T})$ & $641(\mathrm{D} \rightarrow \mathrm{V})$ & $\begin{array}{l}\text { Transactivation } \downarrow \\
\text { Affinity for ligand } \downarrow \text { (x 3) } \\
\text { Nuclear translocation: } 22 \text { min } \\
\text { Abnormal interaction with GRIP1 }\end{array}$ & Homozygous & $\begin{array}{l}\text { Hypertension } \\
\text { Hypokalemic alkalosis }\end{array}$ \\
\hline Karl et $\mathrm{al}^{33}$ & 4 bp deletion is & exon-intron 6 & $\begin{array}{l}\text { hGR } \alpha \text { number: } 50 \% \text { of control } \\
\text { Inactivation of the affected allele }\end{array}$ & Heterozygous & $\begin{array}{l}\text { Hirsutism } \\
\text { Male-pattern hair-loss } \\
\text { Menstrual irregularities }\end{array}$ \\
\hline 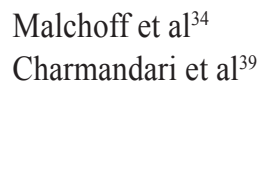 & $2185(\mathrm{G} \rightarrow \mathrm{A})$ & $729(\mathrm{~V} \rightarrow \mathrm{I})$ & $\begin{array}{l}\text { Transactivation } \downarrow \\
\text { Affinity for ligand } \downarrow \text { (x 2) } \\
\text { Nuclear translocation: } 120 \text { min } \\
\text { Abnormal interaction with GRIP1 }\end{array}$ & Homozygous & $\begin{array}{l}\text { Precocious puberty } \\
\text { Hyperandrogenism }\end{array}$ \\
\hline $\begin{array}{l}\text { Karl et } \mathrm{al}^{31} \\
\text { Kino et } \mathrm{al}^{35} \\
\text { Charmandari et al }{ }^{39}\end{array}$ & $1676(\mathrm{~T} \rightarrow \mathrm{A})$ & $559(\mathrm{I} \rightarrow \mathrm{N})$ & $\begin{array}{l}\text { Transactivation } \downarrow \\
\text { Decrease in hGR binding sites } \\
\text { Transdominance }(+) \\
\text { Nuclear translocation: } 180 \\
\text { Abnormal interaction with GRIP1 }\end{array}$ & Heterozygous & $\begin{array}{l}\text { Hypertension } \\
\text { Oligospermia } \\
\text { Infertility }\end{array}$ \\
\hline $\begin{array}{l}\text { Ruiz et } \mathrm{al}^{36} \\
\text { Charmandari et } \mathrm{al}^{41}\end{array}$ & $1430(\mathrm{G} \rightarrow \mathrm{A})$ & $477(\mathrm{R} \rightarrow \mathrm{H})$ & $\begin{array}{l}\text { Transactivation } \downarrow \\
\text { No DNA binding } \\
\text { Nuclear translocation: } 20 \mathrm{~min}\end{array}$ & Heterozygous & $\begin{array}{l}\text { Hirsutism } \\
\text { Fatigue } \\
\text { Hypertension }\end{array}$ \\
\hline $\begin{array}{l}\text { Ruiz et al. }{ }^{36} \\
\text { Charmandari et } \mathrm{al}^{41}\end{array}$ & $2035(\mathrm{G} \rightarrow \mathrm{A})$ & $679(\mathrm{G} \rightarrow \mathrm{S})$ & $\begin{array}{l}\text { Transactivation } \downarrow \\
\text { Affinity for ligand } \downarrow \text { (x 2) } \\
\text { Nuclear translocation: } 30 \text { min } \\
\text { Abnormal interaction with GRIP1 }\end{array}$ & Heterozygous & $\begin{array}{l}\text { Hirsutism } \\
\text { Fatigue } \\
\text { Hypertension }\end{array}$ \\
\hline $\begin{array}{l}\text { Mendonca et } \mathrm{al}^{37} \\
\text { Charmandari et } \mathrm{al}^{39}\end{array}$ & $1712(\mathrm{~T} \rightarrow \mathrm{C})$ & $571(\mathrm{~V} \rightarrow \mathrm{A})$ & $\begin{array}{l}\text { Transactivation } \downarrow \\
\text { Affinity for ligand } \downarrow \text { (x } 6 \text { ) } \\
\text { Nuclear translocation: } 25 \text { min } \\
\text { Abnormal interaction with GRIP1 }\end{array}$ & Homozygous & $\begin{array}{l}\text { Ambiguous genitalia } \\
\text { Hypertension } \\
\text { Hypokalemia } \\
\text { Hyperandrogenism }\end{array}$ \\
\hline $\begin{array}{l}\text { Vottero et } \mathrm{al}^{38} \\
\text { Charmandari et } \mathrm{al}^{39}\end{array}$ & $2241(\mathrm{~T} \rightarrow \mathrm{G})$ & $747(\mathrm{I} \rightarrow \mathrm{M})$ & $\begin{array}{l}\text { Transactivation } \downarrow \\
\text { Transdominance }(+) \\
\text { Affinity for ligand } \downarrow \text { ( } x 2 \text { ) } \\
\text { Nuclear translocation } \downarrow \\
\text { Abnormal interaction with GRIP1 }\end{array}$ & Heterozygous & $\begin{array}{l}\text { Cystic acne } \\
\text { Hirsutism } \\
\text { Oligo-amenorrhea }\end{array}$ \\
\hline Charmandari et $\mathrm{al}^{40}$ & $2318(\mathrm{~T} \rightarrow \mathrm{C})$ & $773(\mathrm{~L} \rightarrow \mathrm{P})$ & $\begin{array}{l}\text { Transactivation } \downarrow \\
\text { Transdominance }(+) \\
\text { Affinity for ligand } \downarrow \text { (x 2.6) } \\
\text { Nuclear translocation: } 30 \text { min } \\
\text { Abnormal interaction with GRIP1 }\end{array}$ & Heterozygous & $\begin{array}{l}\text { Fatigue } \\
\text { Anxiety } \\
\text { Acne } \\
\text { Hirsutism } \\
\text { Hypertension }\end{array}$ \\
\hline Charmandari et $\mathrm{al}^{42}$ & $2209(\mathrm{~T} \rightarrow \mathrm{C})$ & $737(\mathrm{~F} \rightarrow \mathrm{L})$ & $\begin{array}{l}\text { Transactivation } \downarrow \\
\text { Transdominance }(+) \\
\text { Affinity for ligand } \downarrow \text { (x } 1.5) \\
\text { Nuclear translocation: } 180 \text { min }\end{array}$ & Heterozygous & $\begin{array}{l}\text { Hypertension } \\
\text { Hypokalemia }\end{array}$ \\
\hline McMahon et $\mathrm{al}^{22}$ & $\begin{array}{l}2 \text { bp deletion } \\
\text { at nt } 2318-9\end{array}$ & 773 & $\begin{array}{l}\text { Transactivation } \downarrow \\
\text { Affinity for ligand: absent } \\
\text { No suppression of IL-6 }\end{array}$ & Homozygous & $\begin{array}{l}\text { Hypoglycemia } \\
\text { Fatigability with feeding } \\
\text { Hypertension }\end{array}$ \\
\hline
\end{tabular}


Table 2. (continued) Mutations of the human glucocorticoid receptor gene causing Primary Generalized Glucocorticoid Resistance

\begin{tabular}{|c|c|c|c|c|c|}
\hline \multirow[b]{2}{*}{ Author (Reference) } & \multicolumn{2}{|c|}{ Mutation position } & \multirow[b]{2}{*}{ Molecular mechanisms } & \multirow[b]{2}{*}{ Genotype } & \multirow[b]{2}{*}{ Phenotype } \\
\hline & cDNA & Amino acid & & & \\
\hline Nader et $\mathrm{al}^{21}$ & $2141(\mathrm{G} \rightarrow \mathrm{A})$ & $714(\mathrm{R} \rightarrow \mathrm{Q})$ & $\begin{array}{l}\text { Transactivation } \downarrow \\
\text { Transdominance }(+) \\
\text { Affinity for ligand } \downarrow \text { (x 2) } \\
\text { Nuclear translocation } \downarrow \\
\text { Abnormal interaction with GRIP1 }\end{array}$ & Heterozygous & $\begin{array}{l}\text { Hypoglycemia } \\
\text { Hypokalemia } \\
\text { Hypertension } \\
\text { Mild clitoromegaly } \\
\text { Advanced bone age } \\
\text { Precocious pubarche }\end{array}$ \\
\hline Bouligand et $\mathrm{al}^{43}$ & $1405(\mathrm{C} \rightarrow \mathrm{T})$ & $469(\mathrm{R} \rightarrow \mathrm{X})$ & $\begin{array}{l}\text { Transactivation } \downarrow \\
\text { Ligand-binding sites } \downarrow \\
\text { No DNA binding } \\
\text { No nuclear translocation }\end{array}$ & Heterozygous & $\begin{array}{l}\text { Adrenal hyperplasia } \\
\text { Hypertension } \\
\text { Hypokalemia }\end{array}$ \\
\hline Zhu Hui-juan et al ${ }^{44}$ & $1667(\mathrm{G} \rightarrow \mathrm{T})$ & $556(\mathrm{~T} \rightarrow \mathrm{I})$ & Not studied yet & Heterozygous & Adrenal incidentaloma \\
\hline Roberts et $\mathrm{al}^{45}$ & $1268(\mathrm{~T} \rightarrow \mathrm{C})$ & $423(\mathrm{~V} \rightarrow \mathrm{A})$ & $\begin{array}{l}\text { Transactivation } \downarrow \\
\text { Affinity for ligand: } \mathrm{N} \\
\text { No DNA binding } \\
\text { Nuclear translocation: } 35 \text { min } \\
\text { Interaction with GRIP1: N }\end{array}$ & Heterozygous & $\begin{array}{l}\text { Fatigue } \\
\text { Anxiety } \\
\text { Hypertension }\end{array}$ \\
\hline Nicolaides et al ${ }^{46}$ & $1724(\mathrm{~T} \rightarrow \mathrm{G})$ & $575(\mathrm{~V} \rightarrow \mathrm{G})$ & $\begin{array}{l}\text { Transactivation } \downarrow \\
\text { Transrepression } \\
\text { Affinity for ligand } \downarrow \text { (x 2) } \\
\text { Nuclear translocation } \downarrow \\
\text { Abnormal interaction with GRIP1 }\end{array}$ & Heterozygous & $\begin{array}{l}\text { Melanoma } \\
\text { Asymptomatic daughters }\end{array}$ \\
\hline Nicolaides et $\mathrm{al}^{47}$ & $2177(\mathrm{~A} \rightarrow \mathrm{G})$ & $726(\mathrm{H} \rightarrow \mathrm{R})$ & $\begin{array}{l}\text { Transactivation } \downarrow \\
\text { Transrepression } \downarrow \\
\text { Affinity for ligand } \downarrow \text { ( } \quad 2 \text { ) } \\
\text { Nuclear translocation } \downarrow \\
\text { Abnormal interaction with GRIP1 }\end{array}$ & Heterozygous & $\begin{array}{l}\text { Hirsutism, Acne, } \\
\text { Alopecia, Anxiety, } \\
\text { Fatigue } \\
\text { Irregular menstrual cycles }\end{array}$ \\
\hline
\end{tabular}

the hGR $\alpha$ V423A displayed reduced transcriptional activity, had a significant reduction in its ability to bind to DNA sequences within the promoter regions of glucocorticoid-target genes, and required a longer time to translocate into the nucleus following exposure to dexamethasone, compared with the wild-type receptor (Figure 4A and 4B). ${ }^{45}$ Structural biology studies highlighted the critical role of the hydrophobic valine at this position within the first zinc finger of the DBD of the receptor. The hydrophobic nature of valine at amino acid position 423 protects the four zinc-binding cysteines (C421, C424, C438, and C441) from the destructive diffusion of water molecules. The substitution of valine by alanine results in water diffusion into the ion-binding region of the mutant receptor and causes reduced binding of the mutant receptor hGR $\alpha$ V423A to GREs. ${ }^{45}$

The second mutation in the NR3C1 gene was identified in a 70-year-old man and his two daughters, who had increased urinary free cortisol excretion and showed resistance of the HPA axis to dexamethasone suppression without any symptoms or signs suggestive of Cushing syndrome. ${ }^{46}$ Sequencing of the NR $3 C 1$ gene revealed a substitution of valine $(\mathrm{V})$ by glycine $(\mathrm{G})$ at amino acid 575 in the LBD of the receptor. ${ }^{46}$ Compared with the wild-type receptor, the hGR $\alpha$ V 575G had 50\% lower affinity for dexamethasone, displayed reduced transactivation of glucocorticoid-responsive genes, had a 2.5-fold delay in nuclear translocation, and interacted with the GRIP1 coactivator mostly through its AF-1 
domain (Figure 4C). ${ }^{46}$ This impaired interaction of the mutant receptor with the GRIP1 coactivator was further confirmed by structural biology assays which showed that the substitution of valine by glycine at amino acid position 575 resulted in the loss of two noncovalent bonds observed between the valine of the wild-type receptor and the LXXLL motif of the GRIP1 coactivator. Finally, the hGR $\alpha$ V575G demonstrated significantly increased ability to transrepress NF- $\kappa B$-responsive genes (Figure 4C) ${ }^{46}$

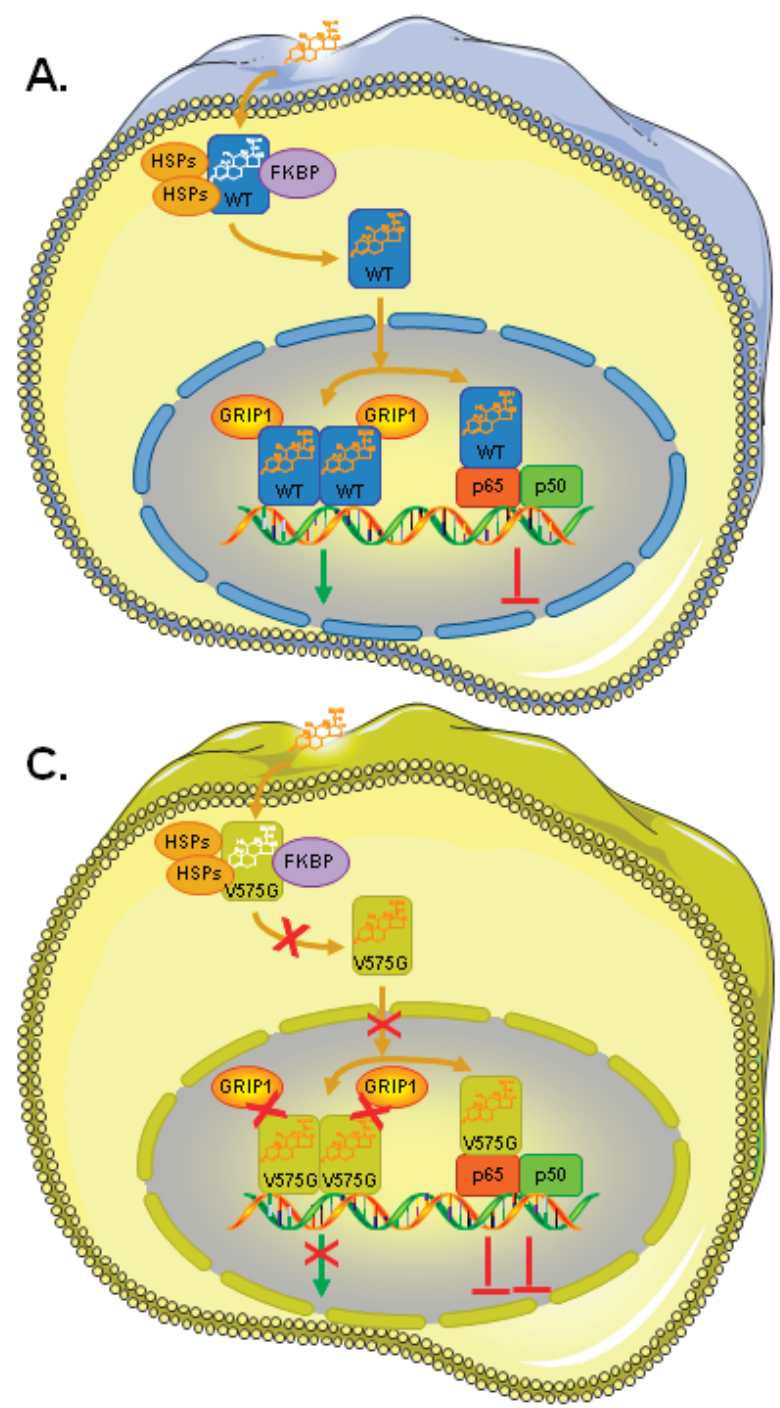

The last point mutation in the $N R 3 C l$ gene was identified in a 30-year-old woman with hirsutism, acne, alopecia, anxiety, fatigue, and irregular menstrual cycles without any clinical features of Cushing syndrome. ${ }^{47}$ Endocrinologic evaluation revealed elevated 08:00 h plasma ACTH, serum cortisol concentrations, and increased urinary free cortisol (UFC) excretion. There was resistance of the HPA axis to overnight dexamethasone suppression, while a pituitary magnetic resonance imaging scan was normal. ${ }^{47}$

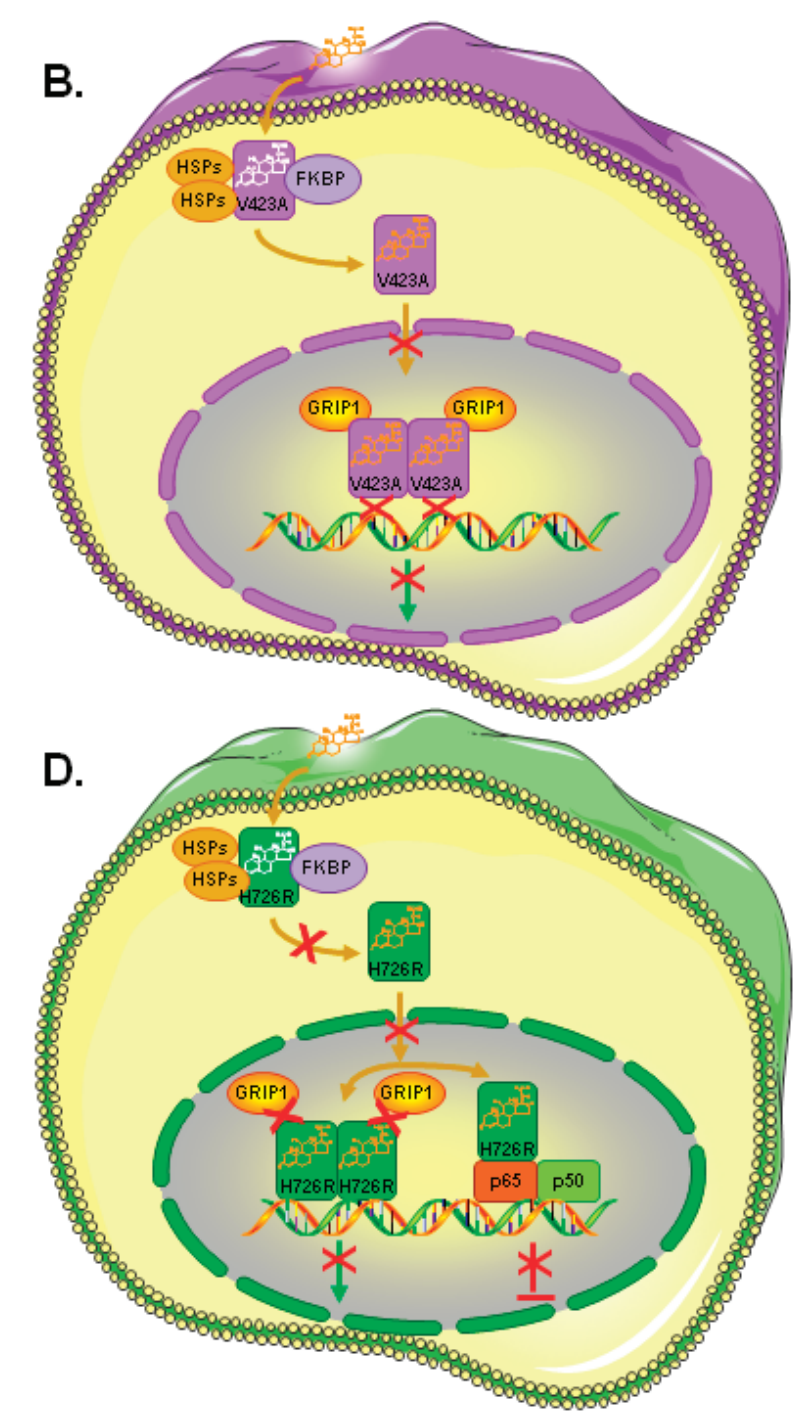

Figure 4. Molecular mechanisms of action of the mutant receptors hGR $\alpha$ V423A, hGR $\alpha$ V575G, and hGR $\alpha$ H726R, compared with the wild-type hGR $\alpha$. (A) The hGR $\alpha$ WT-mediated signal transduction. (B) Molecular mechanisms of action of the hGR $\alpha$ V423A. (C) Molecular mechanisms of action of the hGRaV575G. (D) Molecular mechanisms of action of the hGR $\alpha$ H726R. FKBP: immunophilins; GRIP1: glucocorticoid receptor-interacting protein 1; H726R: human glucocorticoid receptor H726R; HSP: heat shock proteins; p50: transcription factor p50; p65: transcription factor p65; V423A: human glucocorticoid receptor V423A; V575G: human glucocorticoid receptor V575G; WT: wild-type human glucocorticoid receptor. 
A novel heterozygous point mutation was identified in the NR3C1 gene, which resulted in histidine $(\mathrm{H})$ to arginine (R) substitution at amino acid position 726 in the LBD of the receptor. ${ }^{47}$ We subsequently elucidated the molecular mechanisms of action of the mutant receptor hGR $\alpha$ H726R causing Primary Generalized Glucocorticoid Resistance. The hGR $\alpha$ H726R displayed reduced ability to transactivate target genes and to transrepress NF- $\mathrm{kB}-$ responsive genes, had $55 \%$ lower affinity for the ligand and a 4-fold delay in cytoplasmic-to-nuclear translocation following dexamethasone-induced activation, and interacted with the GRIP1 coactivator mostly through its AF-1 domain (Figure 4D) ${ }^{47}$ Structural biology studies showed that the H726R mutation caused a structural shift in the rigidity of helix 10 within the LBD of the receptor, which resulted in reduced flexibility and decreased affinity of the mutant receptor for the ligand. ${ }^{47}$

\section{DIAGNOSIS}

When Primary Generalized Glucocorticoid Resistance is suspected, a detailed personal and family history should be obtained, placing particular emphasis on any clinical manifestations indicating alterations in the activity of the HPA axis. ${ }^{11-13,15-18}$ Symptoms such as seizures, headaches or visual impairment should be carefully evaluated. The irregularity of menstrual cycles in women should be methodically documented. Furthermore, the growth, development and pubertal stage in children should be assessed. On clinical examination, particular attention should be paid to signs suggestive of mineralocorticoid and/or androgen excess. ${ }^{11-13,15-18}$

The endocrinologic evaluation includes determination of the $08: 00 \mathrm{~h}$ concentrations of serum cortisol, plasma ACTH, plasma renin activity (recumbent), serum aldosterone, androgens (testosterone, androstenedione, DHEA, DHEAS), and insulin..$^{11-13,15-18}$ The biochemical evaluation consists of measurement of the 08:00h concentrations of total cholesterol, HDL, LDL, triglycerides, and fasting glucose. ${ }^{11-13,15-18}$ Patients with Primary Generalized Glucocorticoid Resistance have increased 24-hour serum cortisol concentrations and elevated 24-hour UFC excretion despite the absence of Cushingoid features; therefore, the 24-h UFC excretion should be determined on 2 or 3 consecutive days to enable accurate diagnosis of the condition. ${ }^{11-13,15-18}$
It is also important to note that patients may display significant variations in the 24-hour UFC excretion and serum cortisol concentrations owing to variations in the impairment of glucocorticoid signal transduction. Indeed, serum cortisol concentrations may be up to 7 - fold higher compared with the highest value of its normal range, while the 24-hour UFC excretion may be up to 50-fold higher when compared with the upper normal range. In addition, the 08:00h plasma ACTH concentrations may be normal or high, while the circadian pattern of secretion of both ACTH and cortisol, as well as their responsiveness to any external or internal stressful stimuli, are normal. ${ }^{11-13,15-18}$

The dexamethasone suppression test remains one of the most useful diagnostic tools to evaluate the responsiveness of the HPA axis and to determine the appropriate dose to be administered when treatment is commenced. ${ }^{11-13,15-18}$ To this end, increasing doses of dexamethasone $(0.3,0.6,1.0,1.5,2.0,2.5,3.0 \mathrm{mg})$ are administered per os at midnight every other day and serum cortisol and dexamethasone concentrations are determined at 08:00h the following morning. It is also important to determine the serum concentrations of dexamethasone concurrently in order to exclude the possibility of non-adherence to treatment, increased metabolic clearance or reduced absorption of the medication. ${ }^{18}$ The HPA axis may display significant variation in its resistance to dexamethasone suppression depending on the impairment of the glucocorticoid signal transduction. The dose of dexamethasone required to suppress serum cortisol concentrations by $50 \%$ may be up to 7.5 -fold higher than that required to achieve the same degree of HPA axis suppression in normal subjects. ${ }^{18}$

Dexamethasone-binding assays and thymidine incorporation assays remain the two main molecular biology methods that confirm the diagnosis of Primary Generalized Glucocorticoid Resistance. ${ }^{11-13,15-18}$ In dexamethasone-binding assays, the administered tritiated dexamethasone binds to the mutated hGR of the patient's peripheral leukocytes with lower affinity compared with the wild-type hGR of the control subject in patients with mutations in the LBD of the receptor. In thymidine incorporation assays, the patient displays higher resistance to suppression of phytohemaglutinin-stimulated thymidine incorporation in response to dexamethasone compared with 
the control subject. Finally, $N R 3 C 1$ gene insertions, deletions or mutations are identified by sequencing of the coding region (including the intron-exon junctions) of the gene in most but not all subjects with the condition. ${ }^{11-13,15-18}$

\section{TREATMENT}

The main aim of treatment in primary generalized glucocorticoid resistance is to suppress the increased secretion of ACTH, thereby suppressing the increased production of adrenal steroids with mineralocorticoid and androgenic activity. Treatment involves administration of high doses of mineralocorticoid-sparing synthetic glucocorticoids, such as dexamethasone (1-3 mg given once daily at night), which activate the mutant and/or wild-type hGR $\alpha$ and suppress the endogenous secretion of ACTH in affected subjects. ${ }^{11-13,15-18}$ Clinicians should carefully titrate the dose of dexamethasone according to the clinical manifestations and biochemical profile of the patients. It is important to achieve adequate suppression of the HPA axis to prevent the development of an ACTH-secreting adenoma. ${ }^{11-13,15-18}$

\section{BEYOND NR3C1 GENE MUTATIONS: PRIMARY GENERALIZED GLUCOCORTICOID RESISTANCE IN THE ERA OF NEXT- GENERATION SEQUENCING}

Although the clinical manifestations of primary generalized glucocorticoid resistance are primarily caused by point mutations, insertions or deletions in the $\mathrm{NR} 3 \mathrm{Cl}$ gene encoding defective hGRs, some patients with this condition do not harbor any $\mathrm{NR} 3 \mathrm{Cl}$ gene mutations, suggesting a possible role of other genes encoding proteins involved in the glucocorticoid signaling pathway or important hGR partners. One such protein is the FK506-Binding Immunophilin FKBP51, which forms a heterocomplex with the hGR $\alpha$ in the absence of glucocorticoids and is responsible for the cytoplasmic localization of the receptor. Interestingly, some New World primates had elevated expression of FKBP51 and decreased levels of FKBP52, which both contributed to the phenotype of glucocorticoid resistance. ${ }^{48}$ It was subsequently shown that FKBP51 and FKBP52 have opposite effects in nuclear translocation of GR in mammalian cells, indicating that any imbalance between them could ultimately lead to glucocorticoid resistance or hypersensitivity. ${ }^{49}$ In addition to the FKBP proteins, the chaperone proteins HSP90 and HSP70 are thought to play a role in determining tissue sensitivity to glucocorticoids. However, their role in glucocorticoid resistance is controversial, given that only a few studies have shown an association between abnormal expression of HSP90/HSP70 and glucocorticoid resistance. ${ }^{50-53}$ In the era of next-generation sequencing, when a patient is suspected of having primary generalized glucocorticoid resistance, we suggest sequencing of the $\mathrm{NR} 3 \mathrm{Cl}$ gene as well as of other genes that encode proteins known to be involved in the glucocorticoid signaling cascade. The application of novel technologies, such as whole-exome sequencing and whole genome sequencing, may uncover other causes of Primary Generalized Glucocorticoid Resistance that may relate to the pathogenesis of this condition.

\section{FUNDING}

This work was supported by the European Union (European Social Fund - ESF) and Greek national funds through the Operational Program "Education and Lifelong Learning" of the National Strategic Reference Framework (NSRF) - Research Funding Program: THALIS - University of Athens (UOA), Athens, Greece.

\section{REFERENCES}

1. Charmandari E, Tsigos C, Chrousos GP, 2005 Endocrinology of the stress response. Annu Rev Physiol 67: 259-284.

2. Chrousos GP, Kino T, 2005 Intracellular glucocorticoid signaling: A formerly simple system turns stochastic. Sci STKE. 304: pe48.

3. Chrousos GP, Kino T, 2007 Glucocorticoid action networks and complex psychiatric and/or somatic disorders. Stress 10: 213-219.

4. Nicolaides NC, Charmandari E, Chrousos GP, Kino T, 2014 Circadian endocrine rhythms: the hypothalamicpituitary-adrenal axis and its actions. Ann N Y Acad Sci 1318: 71-80.

5. Nicolaides NC, Kyratzi E, Lamprokostopoulou A, Chrousos GP, Charmandari E, 2015 Stress, the stress system and the role of glucocorticoids. Neuroimmunomodulation 22: 6-19.

6. Nicolaides NC, Galata Z, Kino T, Chrousos GP, Charmandari E, 2010 The human glucocorticoid receptor: 
Molecular basis of biologic function. Steroids 75: 1-12.

7. Chrousos GP, 2009 Stress and disorders of the stress system. Nat Rev Endocrinol 5: 374-81.

8. Nicolaides NC, Charmandari E, Chrousos GP, 2015 The hypothalamic-pituitary-adrenal axis in human health and disease. In: Cokkinos DV, editor. Introduction in Translational Cardiovascular Research. Springer International Publishing Switzerland; p. 91-107.

9. Charmandari E, Nicolaides NC, Chrousos GP, 2014 Adrenal insufficiency. Lancet 383: 2152-2167.

10. Quax RA, Manenschijn L, Koper JW, et al, 2013 Glucocorticoid sensitivity in health and disease. Nat Rev Endocrinol 9: 670-686.

11. Charmandari E, 2011 Primary generalized glucocorticoid resistance and hypersensitivity. Horm Res Paediatr 76: 145-155.

12. Charmandari E, 2012 Primary generalized glucocorticoid resistance and hypersensitivity: the end-organ involvement in the stress response. Sci Signal 5: pt5.

13. Charmandari E, Kino T, Chrousos GP, 2013 Primary generalized familial and sporadic glucocorticoid resistance (Chrousos syndrome) and hypersensitivity. Endocr Dev 24: 67-85.

14. Nicolaides NC, Charmandari E, Chrousos GP, Kino T, 2014 Recent advances in the molecular mechanisms determining tissue sensitivity to glucocorticoids: novel mutations, circadian rhythm and ligand-induced repression of the human glucocorticoid receptor. BMC Endocr Disord 14: 71.

15. Charmandari E, Kino T, 2010 Chrousos syndrome: a seminal report, a phylogenetic enigma and the clinical implications of glucocorticoid signaling changes. Eur J Clin Invest 40: 932-942.

16. Charmandari E, Kino T, Ichijo T, Chrousos GP, 2008 Generalized glucocorticoid resistance: clinical aspects, molecular mechanisms, and implications of a rare genetic disorder. J Clin Endocrinol Metab 93: 1563-1572.

17. Chrousos G, 2011 Q\&A: primary generalized glucocorticoid resistance. BMC Med 9: 27.

18. Nicolaides NC, Charmandari E, 2015 Chrousos syndrome: from molecular pathogenesis to therapeutic management. Eur J Clin Invest 45: 504-514.

19. Chrousos GP, Vingerhoeds A, Brandon D, et al, 1982 Primary cortisol resistance in man. A glucocorticoid receptor-mediated disease. J Clin Invest 69: 1261-1269.

20. Chrousos GP, Detera-Wadleigh SD, Karl M, 1993 Syndromes of glucocorticoid resistance. Ann Intern Med 119: 1113-1124.

21. Nader N, Bachrach BE, Hurt DE, et al, 2010 A novel point mutation in the helix 10 of the human glucocorticoid receptor causes generalized glucocorticoid resistance by disrupting the structure of the ligand-binding domain. J Clin Endocrinol Metab 95: 2281-2285.

22. McMahon SK, Pretorius CJ, Ungerer JP, et al, 2010 Neonatal complete generalized glucocorticoid resistance and growth hormone deficiency caused by a novel ho- mozygous mutation in Helix 12 of the ligand binding domain of the glucocorticoid receptor gene (NR3C1). J Clin Endocrinol Metab 95: 297-302.

23. Bamberger CM, Bamberger AM, de Castro M, Chrousos GP, 1995 Glucocorticoid receptor $\beta$, a potential endogenous inhibitor of glucocorticoid action in humans. J Clin Invest 95: 2435-2441.

24. Charmandari E, Chrousos GP, Ichijo T, et al, 2005 The human glucocorticoid receptor (hGR) $\beta$ isoform suppresses the transcriptional activity of hGR $\alpha$ by interfering with formation of active coactivator complexes. Mol Endocrinol 19: 52-64.

25. Yudt MR, Jewell CM, Bienstock RJ, Cidlowski JA, 2003 Molecular origins for the dominant negative function of human glucocorticoid receptor $\beta$. Mol Cell Biol 23: 4319-4330.

26. Kino T, Manoli I, Kelkar S, Wang Y, Su YA, Chrousos GP, 2009 Glucocorticoid receptor (GR) $\beta$ has intrinsic, GR $\alpha$-independent transcriptional activity. Biochem Biophys Res Commun 381: 671-675.

27. Kino T, Su YA, Chrousos GP, 2009 Human glucocorticoid receptor isoform beta: recent understanding of its potential implications in physiology and pathophysiology. Cell Mol Life Sci 66: 3435-3448.

28. Oakley RH, Cidlowski JA, 2011 Cellular processing of the glucocorticoid receptor gene and protein: new mechanisms for generating tissue-specific actions of glucocorticoids. J Biol Chem 286: 3177-3184.

29. Lu NZ, Cidlowski JA, 2005 Translational regulatory mechanisms generate N-terminal glucocorticoid receptor isoforms with unique transcriptional target genes. Mol Cell 18: 331-342.

30. Nader N, Chrousos GP, Kino T, 2009 Circadian rhythm transcription factor CLOCK regulates the transcriptional activity of the glucocorticoid receptor by acetylating its hinge region lysine cluster: potential physiological implications. FASEB J 23: 1572-1583.

31. Karl M, Lamberts SW, Koper JW, 1996 Cushing's disease preceded by generalized glucocorticoid resistance: clinical consequences of a novel, dominant-negative glucocorticoid receptor mutation. Proc Assoc Am Physicians 108: 296-307.

32. Hurley DM, Accili D, Stratakis CA, 1991 Point mutation causing a single amino acid substitution in the hormone binding domain of the glucocorticoid receptor in familial glucocorticoid resistance. J Clin Invest 87 : 680-686.

33. Karl M, Lamberts SW, Detera-Wadleigh SD, et al, 1993 Familial glucocorticoid resistance caused by a splice site deletion in the human glucocorticoid receptor gene. J Clin Endocrinol Metab 76: 683-689.

34. Malchoff DM, Brufsky A, Reardon G, et al, 1993 A mutation of the glucocorticoid receptor in primary cortisol resistance. J Clin Invest 91: 1918-1925.

35. Kino T, Stauber RH, Resau JH, Pavlakis GN, Chrousos GP, 2001 Pathologic human GR mutant has a transdomi- 
nant negative effect on the wild-type GR by inhibiting its translocation into the nucleus: importance of the ligand-binding domain for intracellular GR trafficking. J Clin Endocrinol Metab 86: 5600-5608.

36. Ruiz M, Lind U, Gafvels M, et al, 2001 Characterization of two novel mutations in the glucocorticoid receptor gene in patients with primary cortisol resistance. Clin Endocrinol (Oxf) 55: 363-371.

37. Mendonca BB, Leite MV, de Castro M, et al, 2002 Female pseudohermaphroditism caused by a novel homozygous missense mutation of the GR gene. J Clin Endocrinol Metab 87: 1805-1809.

38. Vottero A, Kino T, Combe H, Lecomte P, Chrousos GP, 2002 A novel, C-terminal dominant negative mutation of the GR causes familial glucocorticoid resistance through abnormal interactions with p160 steroid receptor coactivators. J Clin Endocrinol Metab 87: 2658-2667.

39. Charmandari E, Kino T, Vottero A, Souvatzoglou E, Bhattacharyya N, Chrousos GP, 2004 Natural glucocorticoid receptor mutants causing generalized glucocorticoid resistance: Molecular genotype, genetic transmission and clinical phenotype. J Clin Endocrinol Metab 89: 1939-1949.

40. Charmandari E, Raji A, Kino T, et al, 2005 A novel point mutation in the ligand-binding domain (LBD) of the human glucocorticoid receptor (hGR) causing generalized glucocorticoid resistance: the importance of the $\mathrm{C}$ terminus of hGR LBD in conferring transactivational activity. J Clin Endocrinol Metab 90: 3696-3705.

41. Charmandari E, Kino T, Ichijo T, Zachman K, Alatsatianos A, Chrousos GP, 2006 Functional characterization of the natural human glucocorticoid receptor (hGR) mutants hGR $\alpha$ R477H and hGRbG679S associated with generalized glucocorticoid resistance. J Clin Endocrinol Metab 91: 1535-1543.

42. Charmandari E, Kino T, Ichijo T, et al, 2007 A novel point mutation in helix 11 of the ligand-binding domain of the human glucocorticoid receptor gene causing generalized glucocorticoid resistance. J Clin Endocrinol Metab 92: 3986-3990.

43. Bouligand J, Delemer B, Hecart AC, et al, 2010 Familial glucocorticoid receptor haploinsufficiency by non-sense mediated mRNA decay, adrenal hyperplasia and apparent mineralocorticoid excess. PLoS One 5: e13563.

44. Zhu HJ, Dai YF, Wang O, et al, 2011 Generalized glucocorticoid resistance accompanied with an adreno- cortical adenoma and caused by a novel point mutation of human glucocorticoid receptor gene. Chin Med J (Engl) 124: 551-555.

45. Roberts ML, Kino T, Nicolaides NC, et al, 2013 A novel point mutation in the DNA-binding domain (DBD) of the human glucocorticoid receptor causes primary generalized glucocorticoid resistance by disrupting the hydrophobic structure of its DBD. J Clin Endocrinol Metab 98: E790-E795.

46. Nicolaides NC, Roberts ML, Kino T, et al, 2014 A novel point mutation of the human glucocorticoid receptor gene causes primary generalized glucocorticoid resistance through impaired interaction with the LXXLL motif of the p160 coactivators: dissociation of the transactivating and transreppressive activities. J Clin Endocrinol Metab 99: E902-E907.

47. Nicolaides NC, Geer EB, Vlachakis D, et al, 2015 A Novel Mutation of the hGR Gene Causing Chrousos Syndrome. Eur J Clin Invest 45: 782-791.

48. Scammell JG, Denny WB, Valentine DL, Smith DF, 2001 Overexpression of the FK506-binding immunophilin FKBP51 is the common cause of glucocorticoid resistance in three New World primates. Gen Comp Endocrinol 124: 152-165.

49. Wochnik GM, Ruegg J, Abel GA, Schmidt U, Holsboer F, Rein T, 2005 FK506-binding proteins 51 and 52 differentially regulate dynein interaction and nuclear translocation of the glucocorticoid receptor in mammalian cells. J Biol Chem 280: 4609-4616.

50. Kojika S, Sugita K, Inukai T, et al, 1996 Mechanisms of glucocorticoid resistance in human leukemic cells: implication of abnormal 90 and $70 \mathrm{kDa}$ heat shock proteins. Leukemia 10: 994-999.

51. Qian X, Zhu Y, Xu W, Lin Y, 2001 Glucocorticoid receptor and heat shock protein 90 in peripheral blood mononuclear cells from asthmatics. Chin Med J (Engl) 114: 1051-1054.

52. Matysiak M, Makosa B, Walczak A, Selmaj K, 2008 Patients with multiple sclerosis resisted to glucocorticoid therapy: abnormal expression of heat-shock protein 90 in glucocorticoid receptor complex. Mult Scler 14: 919-926.

53. Tissing WJ, Meijerink JP, den Boer ML, Brinkhof B, Pieters R, 2005 MRNA expression levels of (co) chaperone molecules of the glucocorticoid receptor are not involved in glucocorticoid resistance in pediatric ALL. Leukemia 19: 727-733. 